\title{
Pengembangan Modul untuk Materi Keanekaragaman Makhluk Hidup dengan Tema Kearifan Lokal Tumbuhan Obat untuk Siswa SMP/MTs
}

\author{
Saskia Anggun Khairun Nissa ${ }^{1 *}$, Kasmantoni ${ }^{1}$, Wiji Aziiz Hari Mukti', Suharyati ${ }^{2}$ \\ 'Institut Agama Islam Negeri Bengkulu, Bengkulu, Indonesia \\ ${ }^{2}$ Sekolah Dasar Negeri 73 Seluma, Indonesia \\ "Corresponding author: saskiakhairunisa999@gmail.com
}

\begin{abstract}
Abstrak: Penelitian ini bertujuan untuk mengembangkan modul dengan tema kearifan lokal tanaman obat. Adapun prosedur dan tahap pengembangan dalam penelitian ini yaitu potensi dan masalah, pengumpulan data, desain produk, validasi desain, revisi desain, uji coba produk, dan revisi produk. Penelitian yang dilakukan tidak sampai tahap produksi massal dari produk yang sudah dihasilkan, karena peneliti hanya melihat kelayakan produk berdasarkan penilaian validator, pendidik IPA, sehingga keterbatasan peneliti tidak mencakup semua langkah pengembangan yang ada. Hasil validasi dari 3 dosen Institut Agama Islam Negeri Bengkulu yaitu ahli bahasa, ahli materi, dan ahli desain untuk menguji kelayakan Modul Untuk Materi Keanekaragaman Makhluk Hidup Dengan Tema Kearifan Lokal Tanaman Obat Untuk Siswa SMP/MTS yang dikembangkan dinyatakan "sangat layak" untuk digunakan dalam proses pembelajaran dengan persentase hasil penilaian ahli bahasa sebesar $85 \%$ sedangkan hasil penilaian ahli materi sebesar $85,45 \%$ dan hasil penilaian ahli media sebesar $82,44 \%$. 3. Uji respon dilakukan terhadap 11 orang siswa kelas VII dan 1 orang respon Guru IPA yang ada di MTsN 02 Bengkulu Tengah dinyatakan "sangat praktis" dengan total nilai persentase respon peserta didik sebesar $85,45 \%$ dan persentase respon pendidik sebesar $85,71 \%$ tergolong dalam kategori "sangat layak".
\end{abstract}

Kata Kunci: modul, kearifan lokal, tumbuhan obat

Abstract: This study aims to develop a module with the theme of local wisdom of medicinal plants. The procedures and development stages in this research are potential and problems, data collection, product design, design validation, design revision, product testing, and product revision. The research carried out did not reach the mass production stage of the products that have been produced, because the researchers only looked at the feasibility of the product based on the assessment of the validator, science educator, so that the limitations of the researcher did not cover all the existing development steps. The validation results from 3 Bengkulu State Islamic Institute lecturers, namely linguists, material experts, and design experts to test the feasibility of the Module for Material Diversity of Living Things With the Theme of Local Wisdom of Medicinal Plants for Middle School/MTS Students which was developed was declared "very feasible" to be used in the learning process with the percentage of the results of the linguistic expert's assessment of $85 \%$ while the results of the material expert's assessment of $85.45 \%$ and the results of the media expert's assessment of $82.44 \%$. 3. The response test was carried out on 11 students of class VII and 1 response from a science teacher at MTsN 02 Bengkulu Tengah which was stated to be "very practical" with a total percentage value of student responses of $85.45 \%$ and the percentage of educator responses being $85.71 \%$ classified in the "very feasible" category.

Keywords: modules, local wisdom, medicinal plants

PENDAHULUAN

Makhluk hidup yang hidup di muka bumi sangat beraneka ragam. Oleh karena beragamnya makhluk hidup yang ada maka untuk dapat mempelajarinya satu demi satu. Oleh 
karena itu, diperlukan suatu sistem yang disebut taksonomi untuk mempelajarinya. Dengan taksonomi, makhluk hidup yang memiliki kesamaan dikelompokkan dalam satu kelompok. Dengan demikian, kita dapat mempelajari keanekaragaman tersebut dengan lebih mudah.

Kearifan lokal dalam masyarakat merupakan warisan yang diwariskan secara turun menurun dari generasi ke generasi. Kearifan lokal sebagai suatu pengetahuan yang ditemukan oleh masyarakat lokal tertentu melalui kumpulan pengalaman dalam mencoba dan diintegrasikan dengan pemahaman terhadap budaya dan keadaan alam suatu tempat. Kearifan lokal dipandang sangat bernilai dan mempunyai manfaat tersendiri dalam kehidupan masyarakat, kearifan lokal itu antara lain mencakup pengobatan berbasis tanaman atau tumbuhan.

Dengan pengetahuan dan kearifan lokal yang dimiliki secara turun temurun dari leluhurnya, masyarakat Desa Bajak 1, Kabupaten Bengkulu Tengah memanfaatkan tumbuhan untuk meredakan gejala hingga menyembuhkan beragam penyakit yang diderita. Ada yang langsung dimanfaatkan dan ada juga yang harus diracik dengan tumbuhan obat lainnya. Bahanbahan yang dijadikan ramuan dapat diambil dari bagian akar, daun, bunga, buah maupun kayu . Meskipun belum banyak informan yang menggunakan tumbuhan tradisional sebagai bahan obat, maka masyarakat setempat membudidayakan tumbuhan-tumbuhan tersebut

Tumbuhan berkhasiat obat sebagai salah satu upaya dalam penanggulangan masalah kesehatan jauh sebelum pelayanan kesehatan formal dengan obat-obatan sintetik. Pemanfaatan tumbuhan sebagai obat merupakan salah satu cara masyarakat yang dilakukan secara turun temurun untuk memenuhi kebutuhan terutama untuk mengatasi persoalan terkait dengan kesehatan. Dengan pengetahuan dan kearifan lokal yang dimiliki secara turun temurun dari leluhurnya, masyarakat Indonesia memanfaatkan tumbuhan untuk meredakan gejala hingga menyembuhkan beragam penyakit yang diderita.

Bahan pembelajaran yang dipakai oleh pendidik cenderung terfokus hanya kepada buku pegangan yang dipakai yaitu buku paket yang dipakai dari tahun ke tahun. Dengan demikian dapat mempengaruhi proses perkembangan pengetahuan peserta didik. Selain itu, buku paket yang dipakai oleh pendidik dan peserta didik memuat materi secara umum yang kurang memiliki kaitan terhadap kehidupan sehari-hari peserta didik secara nyata. Proses pembelajaran yang berlangsung seperti ini akan berkesan kurang bermakna sebab peserta didik kurang mengenal materi yang tercantum dalam buku tersebut.

Berdasarkan observasi awal yang dilakukan oleh peneliti pada tanggal 10 Desember 2020 di MTsN 02 Bengkulu Tengah, Permasalahan yang didapatkan dari, hasil wawancara dengan ibu Reni Karlina guru IPA kelas VII di MTs 02 Bengkulu Tengah, ditemukan pada saat observasi, belum adanya bahan ajar modul untuk materi keanekaragaman makhluk hidup dengan tema kearifan lokal di sekolah tersebut. Bahan ajar yang digunakan guru dalam pelaksanaan pembelajaran yaitu buku paket dan Lembar Kerja Siswa(LKS), bentuk fisik dari buku cetak telah lusuh dan beberapa lembar halaman hilang, hal ini karena penggunaan bahan ajar yang digunakan siswa digunakan secara bergantian dari generasi ke generasi.

Wawancara secara langsung dengan guru kelas VII mengenai pembelajaran IPA yang menghubungkan terhadap kondisi lingkungan sekolah dan tempat tinggal serta sosial budaya belum pernah dilakukan, bahkan pengembangan bahan ajar yang di dalamnya memuat kearifan lokal belum pernah dilakukan juga, padahal dengan adanya pembelajaran yang menyesuaikan kondisi lingkungan peserta didik akan mendukung peserta didik Mudah untuk memahami materi pelajaran.

Penelitian dan pengembangan modul sebenarnya sudah banyak dilakukan namun penelitian pengembangan modul berbasis kearifan lokal tanaman obat khususnya di daerah Bajak 1, Bengkulu Tengah terhadap mata pelajaran IPA khususnya materi keanekaragaman makhluk hidup belum dilakukan. Sedangkan untuk penyisipan. Nanik Setyowati,dkk mengembangkan jurnal yang berjudul "Jenis-Jenis Gulma yang Berpotensi sebagai Tanaman Obat bagi Masyarakat Desa Taba Teret, Taba Penanjung, Bengkulu" Menunjukan hasil bahwa, Terdapat 20 jenis tumbuhan yang digunakan oleh masyarakat Desa Taba Teret, Taba Penanjung, Bengkulu sebagai bahan obat tradisional untuk mengobati berbagai jenis penyakit. Penelitian ini bertujuan untuk 
menginventarisir jenis-jenis gulma yang dimanfaatkan sebagai tumbuhan obat bagi masyarakat Suku Rejang, Desa Taba Teret, Taba Penanjung, Bengkulu dan jenis-jenis penyakit yang dapat diobati yang kemudian akan diimplementasikan menjadi artikel yang hanya diterbitkan dan tidak dikembangkan sebagai modul pembelajaran yang diajarkan.

Berdasarkan permasalahan di atas, dibutuhkan adanya pengembangan bahan ajar untuk memperkenalkan kearifan lokal tanaman obat daerah Bajak 1, Kabupaten Bengkulu Tengah. Pengembangan bahan ajar yang dilakukan adalah pengembangan modul dengan tema kearifan lokal tanaman obat. Dengan adanya modul dengan tema kearifan lokal diharapan dapat memudahkan peserta didik SMP/MTS kelas VII memahami materi IPA pada materi keanekaragaman makhluk hidup, serta mengenal kearifan lokal tanaman obat daerah Bajak 1 maupun dapat menerapkan nilai-nilai luhur yang terkandung dalam kearifan lokal. Dari penjelasan diatas, maka peneliti tertarik untuk tema ini menjadi sebuah judul penelitian yaitu: "Pengembangan Modul Untuk Materi Keanekaragaman Makhluk Hidup Dengan Tema Kearifan Lokal Tumbuhan Obat Untuk Siswa SMP/MTS".

\section{METODE PENELITIAN}

Jenis Penelitian yang digunakan adalah penelitian pengembangan (Research \& Development atau $\mathrm{R} \& \mathrm{D}$ ). Metode penelitian dan pengembangan adalah metode penelitian yang digunakan untuk menghasilkan produk tertentu, dan menguji keefektifan produk tersebut. Untuk dapat menghasilkan produk tertentu digunakan penelitian yang bersifat analisis kebutuhan dan untuk menguji keefektifan produk supaya dapat berfungsi di masyarakat luas, maka diperlukan penelitian untuk menguji keefektifan produk yang akan dihasilkan.

Produk penelitian yang dihasilkan melalui penelitian dan pengembangan diantaranya pada media pembelajaran seperti buku teks, modul pembelajaran, video pembelajaran, web pebelajaran, e-learning, lembar kerja peserta didik (LKPD), alat peraga praktikum dan lain sebagainya. Penelitian dan pengembangan merupakan pendekatan penelitian untuk menghasilkan produk baru atau menyempurnakan produk yang telah ada. Produk yang dihasilkan bisa berbentuk software, ataupun hardware seperti buku, modul, paket, program pembelajaran ataupun alat bantu belajar. Penelitian dan pengembangan berbeda dengan penelitian biasa yang hanya menghasilkan saran-saran bagi perbaikan, penelitian dan pengembangan menghasilkan produk yang langsung bisa digunakan. Pada penelitian ini akan dikembangkan dan dihasilkan suatu produk berupa modul pembelajaran dengan tema kearifan lokal.

\section{HASIL DAN PEMBAHASAN}

1. Preview Modul Tema Kearifan Lokal Tumbuhan Obat yang telah dikembangkan
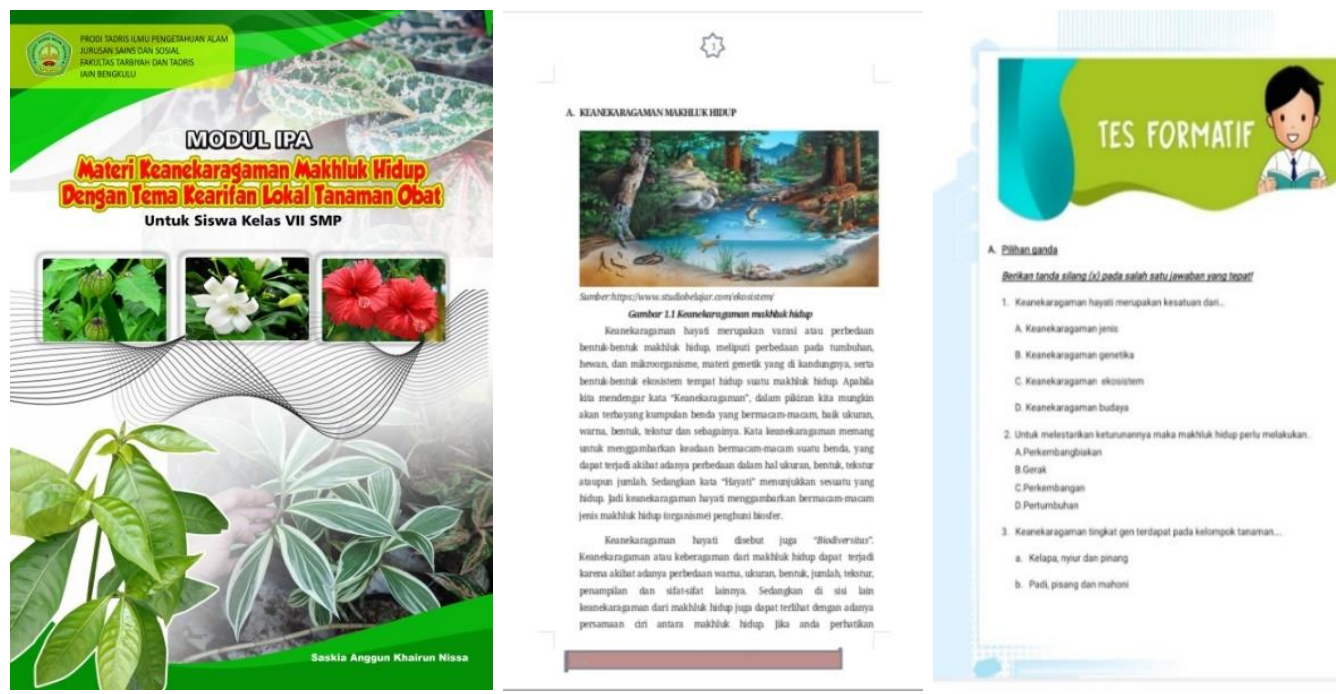

Gambar 1. Tampilan halaman sampul, sub-materi, dan tes formatif modul Tema Kearifan Lokal Tumbuhan Obat yang telah dikembangkan 


\section{Hasil Observasi dan Analisis Kebutuhan}

Berdasarkan hasil observasi pra penelitian di MTsN 02 Bengkulu Tengah. Ditinjau dari segi sarana pendidikan masih kurang maksimalnya bahan ajar seperti peralatan pendidikan, media pendidikan, buku dan sumber belajar lainnya yang memungkinkan bisa menjadi daya tarik saat peserta didik memulai pembelajaran seperti penggunaan buku paket yang disediakan oleh pihak sekolah.

Kegiatan pembelajaran di MTsN 02 Bengkulu Tengah. menggunakan bahan ajar yang sudah disediakan oleh pihak sekolah yaitu buku cetak sebagai sumber materi yang digunakan pendidik yang di dalamnya berisi uraian singkat materi serta soal-soal penunjang materi. Pendidik mata pelajaran IPA yang ada di MTsN 02 Bengkulu Tengah. tidak menggunakan media pembelajaran lain dikarnakan kurangnya media pembelajaran IPA. Pendidik sesekali menggunakan power point untuk mendukung proses pembelajarannya. Sedangkan metode yang digunakan pendidik dalam proses pembelajaran yaitu metode diskusi informasi dan peta konsep.

Berdasarkan Hasil wawancara yang dilakukan pada tanggal 11 Juni 2021 dengan guru IPA, di MTsN 02 Bengkulu Tengah peserta didik kesulitan dalam pembelajaran dikarenakan buku paket yang digunakan terlalu tebal sehingga peserta didik mengalami kesulitan memahami dan menghapal materi. Ditambah lagi materi pada sub bab keanekaragaman makhluk hidup ini banyak dan sangat luas mengakibatkan peserta didik sulit untuk memahami dan mengingat materi. Untuk menunjang kebutuhannya, peserta didk mengunakan internet hanya dirumah saja untuk membantu mengerjakan tugas rumah (PR).

Media yang digunakan oleh guru dalam pembelajaran, sarana dan prasarana yang di gunakan belum terlalu mendukung untuk pemahaman peserta didik hanya sedikit yang mampu memahami, karna setiap peserta didik mempunyai tingkat pemahaman yang berbeda-beda. Kemudian media yang di gunakan dalam proses pembelajaran masih monoton hanya sebatas buku paket yang diperoleh dari pemerintah saja.

Pendidik maupun peserta didik membutuhkan media pembelajaran yang sederhana dan menarik agar bisa menumbuhkan minat baca peserta didik serta memudahkan peseta didik lebih memahami materi.

Berdasarakan penelitian terhadap tanaman obat yang saya teliti dimana obat-obat tersebut yaitu Daun Salung (Psychotria viridiflora Reinw. ex. Blume), Daun Bunga Kembang Sepatu (Hibiscus rosa-sinensis L), Tanaman Pancing (Costus speciosus, (Koenig) J.E Smith), Pasak Bumi (Eurycoma longifolia), Daun Kemuning (Murraya paniculata), Daun sungkai (Peronema canescens), Sirih Merah (Piper crocatum, Benalu Kopi (Scurrula Sp), Tumbuhan Sirsak (Annona muricata L.), Pepaya (Carica papaya), Daun dan Buah Pare (Momordica Charantia), Daun Ketepeng Cina (Cassia alata. L), Kapuk (Ceiba pentandra L.), Ciplukan (Physalis angulate),Tanaman Bangle (Zingiber purpureum Roxb.), Bayam duri (Amaranthus spinousus), Tumbuhan bakung putih (Crinum asiaticum), Daun Keji Beling (Strobilanthes crispus), Tanaman Sembung (Blumea balsamifera), Daun Saga Rambat (Abrus precatorius), Tanaman Beligo atau Kundur (Benincasa hispida), dimana obat-obat tersebut memiliki manfaat dan memiliki kandungan yang sangat baik untuk pengobatan tradisional bagi masyarakat Bajak 1, Kabupaten Bengkulu Tengah.

Pemanfaatan tumbuhan sebagai obat merupakan salah satu cara masyarakat yang dilakukan secara turun temurun untuk memenuhi kebutuhan terutama untuk mengatasi persoalan terkait dengan kesehatan. Tumbuhan berkhasiat obat sebagai salah satu upaya dalam penanggulan masalah kesehatan jauh sebelum pelayanan kesehatan formal dengan obat-obatan sintetik. Dengan pengetahuan dan kearifan lokal yang dimiliki secara turun temurun dari leluhurnya, masyarakat Indonesia memanfaatkan tumbuhan untuk meredakan gejala hingga menyembuhkan beragam penyakit yang diderita. Ada yang langsung dimanfaatkan dan ada juga yang harus diracik dengan tumbuhan obat lainnya. Bahan-bahan yang dijadikan ramuan dapat diambil dari bagian akar, daun, bunga, buah maupun kayu. 


\section{Hasil Perancangan}

Berdasarkan data hasil pra penelitian atau observasi lapangan, maka spesifikasi produk yang akan dikembangankan adalah media pembelajaran yang dapat membantu guru dan siswa dalam proses pembelajaran serta belajar mandiri siswa dimanapun dan kapanpun.

Proses pembuatan media pembelajaran berupa Modul Untuk Materi Keanekaragaman Makhluk Hidup Dengan Tema Kearifan Lokal Tanaman Obat Untuk Siswa SMP/MTS ini melalui beberapa tahap, yaitu:

a. Potensi dan Masalah, peneliti melihat pada saat terjadinya wabah covid-19 mengakibatkan peserta didik belajar dari rumah atau dalam jaringan (daring) sehingga membutuhkan media pembelajaran yang bisa digunakan selama proses pembelajaran dari rumah.

b. Mengumpulkan Data, peneliti mengumpulkan data beberapa data dari angket analisis kebutuhan pada saat observasi awal. Penelitian ini dilaksanakan di MTsN 02 Bengkulu Tengah dengan cara mewawancarai pendidik di kelas VII mengenai proses pembelajaran IPA, media pembelajaran yang digunakan, sikap serta keterampilan karakteristik sumber belajar yang diinginkan pendidik maupun peserta didik. Pendidik membutuhkan bahan ajar alternatif lain sebagai pendukung dalam proses pembelajaran.

c. Desain Produk, Peneliti mendesain media pembelajaran berupa Modul Untuk Materi Keanekaragaman Makhluk Hidup Dengan Tema Kearifan Lokal.

d. Validasi Desain, pada tahap ini peneliti melakukan proses validasi media pembelajaran berupa Modul Dengan Tema Kearifan Lokal. Media pembelajaran ini divalidasi oleh Ibu Nurlia Latifah, M.Pd.Si, berupa instrument penilaian yang menyangkut kelayakan media. Media pembelajaran yang telah divalidasi oleh bapak. Berupa instrument penilaian yang menyangkut kelayakan bahasa. Dan media pembelajaran yang telah divalidasi oleh berupa instrument penilaian yang menyangkut kelayakan materi.

e. Revisi desain, sesuai dengan saran dari validator berupa ahli media, ahli bahasa, dan ahli materi jika media perlu untuk direvisi kembali, peneliti melakukan revisi terhadap media pembelajaran berupa Modul Dengan Tema Kearifan Lokal yang telah dibuat.

f. Uji Coba Produk, Setelah media pembelajaran berupa Modul dengan tema kearifan lokal divalidasi oleh ahli media. Maka peneliti akan melakukan tahap pengujian terhadap media pembelajaran berupa Modul dengan tema kearifan lokal. Peneliti melakukan uji produk pada subjek penelitian yaitu siswa/i MTsN 02 Bengkulu Tengah dengan menggunakan lembar respon siswa/i yang berupa angket.

g. Revisi Produk, revisi ini dilakukan apabila terdapat kekurangan pada media pembelajaran berupa Modul dengan tema kearifan lokal, maka media pembelajaran peneliti direvisi kembali.

\section{Hasil Uji Validasi}

Uji validasi dilakukan oleh validator yang merupakan dosen ahli dibidangnya masingmasing dengan menggunakan lembar instrumen validasi yang telah disiapkan sebelumnya. Validasi produk pengembangan ini dilakukan dengan menggunakan angket, sehingga data yang disajikan merupakan data hasil dari validator yang berupa ahli di bidang bahasa, materi, dan media. Selain memberikan penilaian, validator juga memberikan kritik dan saran terhadap produk pengembangan dibagian dalam angket. Penilaian dari validator ini akan disusun dan menghasilkan data hasil uji kevalidan produk Modul Dengan Tema Kearifan Lokal.

Adapun komponen yang dinilai oleh ahli bahasa dalam kegiatan validasi oleh ahli bahasa adalah sesuai dengan perkembangan siswa, lugas, komunikatif, dialogis dan interaktif, kohernsi dan interaktif, kesesuaian dengan kaedah Bahasa Indonesia yang benar, dan penggunaan istilah, simbol, atau ikon. Hasil penilaian ahli bahasa terhadap modul yang dikebangkan secara persentase adalah $85 \%$ dengan kategori "sangat layak".

Modul yang dikembangkan juga divalidasi oleh ahli materi untuk melihat kesesuaian materi pada modul dengan tingkat kognitif perkembangan siswa. Adapun komponen yang dinilai oleh ahli materi yaitu materi, kejelasan materi, kemutakhiran, merangsang keingintahuan melalui 
media, mengembangkan kecakapan hidup, mengembangkan wawasan intelektual, dan mengandung wawasan kontekstual. Hasil penilaian ahli materi terhadap modul yang dikebangkan secara persentase adalah 85,45\% dengan kategori "sangat layak".

Modul yang dikembangkan juga divalidasi dari segi media yang disajikan dalam modul. Adapun aspek yang dinilai oleh ahli desain diantaranya tampilan untuk menilai daya dukung gambar dan ilustrasi, pemilihan warna, dan tampilan cover Modul Dengan Tema Kearifan Lokal. Persentase hasil validasi oleh ahli media sebesar $82,44 \%$ dengan kategori "sangat layak".

Hasil Uji Produk

Setelah produk melalui tahap validasi oleh ahli materi, ahli media dan ahli bahasa telah selesai diperbaiki, selanjutnya produk diuji cobakan dengan uji coba produk ini terdiri dari 11 orang siswa kelas VII MTsN 02 Bengkulu Tengah. Tahap uji coba produk ini dilakukan di MTsN 02 Bengkulu Tengah. Hasil uji coba produk diperoleh skor tertinggi diperoleh 5 orang siswa dengan jumlah pertanyaan 16 butir. Hasil yang diperoleh dari uji produk bahwa respon pendidik dan peserta didik terhadap media Modul Untuk Materi Keanekaragaman Makhluk Hidup Dengan Tema Kearifan Lokal Tanaman Obat Untuk Siswa SMP/MTS dengan persentase respon peserta didik sebesar $85,45 \%$ tergolong dalam kategori “sangat layak". Dari respons guru tehadap modul yang dikembangkan diperoleh persentase sebesar $85,71 \%$ dan termasuk dalam kategori "sangat layak".

\section{Hasil Produk Akhir}

Hasil akhir dari tahapan ini yaitu memperoleh Modul Untuk Materi Keanekaragaman Makhluk Hidup Dengan Tema Kearifan Lokal Tanaman Obat Untuk Siswa SMP/MTS yang layak dan praktis untuk digunakan. Modul ini diharapkan bisa menjadi media pembelajaran alternatif baru yang bisa membantu dan mendukung proses pembelajaran baik secara konvensional maupun secara daring atau dalam jaringan. Melalui Modul ini juga diharapkan tujuan pembelajaran lebih mudah dicapai serta waktu yang digunakan dalam proses pembelajaran menjadi lebih efektif.

\section{Prototipe Hasil Pengembangan}

Hasil dari penelitian pengembangan ini adalah modul pembelajaran IPA untuk materi keanekaragaman makhluk hidup dengan tema kearifan lokal tanaman obat untuk siswa SMP/MTS yang telah divalidasi oleh dosen para ahli, diantaranya validasi materi, validasi bahasa dan validasi media. Selain itu produk ini juga sudah diuji kelayakan dan kepraktisannya melalui uji skala kecil kepada siswa dan guru IPA di MTsN 02 Bengkulu Tengah. Adapun bagian-bagian dari modul pembelajaran IPA untuk materi keanekaragaman makhluk hidup dengan tema kearifan lokal tanaman obat untuk siswa SMP/MTS adalah sampul modul, kata pengantar modul, daftar isi, pendahuluan, petunjuk penggunaan modul, kompetensi dasar dan indikator pencapaian kompetensi, sub materi 1 - 3, rangkuman, soal evaluasi, kunci jawaban, serta daftar pustaka.

\section{KESIMPULAN}

Berdasarkan pada hasil penelitian dan pembahasan yang telah dilakukan, maka ditarik kesimpulan bahwa: 1. Modul Untuk Materi Keanekaragaman Makhluk Hidup Dengan Tema Kearifan Lokal Tanaman Obat Untuk Siswa SMP/MTS dikembangkan dengan metode Research and Development (R\&D) oleh Sugiyono yang kemudian dibatasi oleh peneliti untuk disesuaikan dengan kebutuhan penelitian dan pengembangan yang dilakukan. Adapun prosedur dan tahap pengembangan dalam penelitian ini yaitu Potensi Dan Masalah, pengumpulan Data, Desain Produk, Validasi Desain, Revisi Desain, Uji Coba Produk, dan Revisi Produk. Penelitian yang dilakukan tidak sampai tahap produksi massal dari produk yang sudah dihasilkan, karena peneliti hanya melihat kelayakan produk berdasarkan penilaian validator, pendidik IPA, sehingga keterbatasan peneliti tidak mencakup semua langkah pengembangan yang ada. 2. Hasil validasi dari 3 dosen Institut Agama Islam Negeri Bengkulu yaitu ahli bahasa, ahli materi, dan ahli desain untuk menguji kelayakan Modul Untuk Materi Keanekaragaman Makhluk Hidup Dengan Tema 
Kearifan Lokal Tanaman Obat Untuk Siswa SMP/MTS yang dikembangkan dinyatakan "sangat layak" untuk digunakan dalam proses pembelajaran dengan persentase hasil penilaian ahli bahasa sebesar $85 \%$ sedangkan hasil penilaian ahli materi sebesar $85,45 \%$ dan hasil penilaian ahli media sebesar $82,44 \%$. 3. Uji respon dilakukan terhadap 11 orang siswa kelas VII dan 1 orang respon Guru IPA yang ada di MTsN 02 Bengkulu Tengah dinyatakan "sangat praktis" dengan total nilai persentase respon peserta didik sebesar $85,45 \%$ dan persentase respon pendidik sebesar $85,71 \%$ tergolong dalam kategori " sangat layak".

\section{DAFTAR PUSTAKA}

Dwi Ratna Anjaning Kusuma Marpaung. (2018). Tumbuhan Obat Dan Kearifan Lokal Masyarakat Di Sekitar Kawasan Tnbg, Desa Sibanggor Julu, Kabupaten Mandailing Natal. Jurnal Biosains, 4(2):85-86.

Elza Minawarti Dewi, Musinah Annisa, dan Dedi Kusnadi. (2018). Pengembangan Modul IPA Berbasis Keterampilan Proses Sains Untuk Mengembangkan Karakter Pada Siswa Kelas V A SDN 007 Tarakan. Jurnal Pendidikan IPA, 8(2):55.

Ervina Dewi, Rahmi Agustina, Miftahul Husna. (2019). Kearifan Lokal Masyarakat Kemukiman Bambi Dalam Mengolah Tanaman Binahong (Anrederaordifolia)Sebagai Tanaman Obat. Jurnal Agroristek. 2(1):24.

Febry Hidayanto, Sriyono, Nur Ngazizah. (2016). Pengembangan Modul Fisika SMA Berbasis Kearifan Lokal Untuk Mengoptimalkan Karakter Peserta Didik. Jurnal Radiasi, 9(1):25.

Ni Ketut Lestari dewil , Mohammad Jamhari, Isnainar. (2017). Kajian Pemanfaatan Tanaman Sebagai Obat Tradisional Di Desa Tolai Kecamatan Torue Kabupaten Parigi Moutong. e-JIP BIOL. 5(2): 92-108.

Rusman. (2016). Model-model Pembelajaran Mengembangkan Profesional Guru. Jakarta: PT. Rajagrafindo Persada

Septina, N., Farida, F., \& Komarudin, K. (2018). Pengembangan Lembar Kerja Siswa Dengan Pendekatan Saintifik Berbasis Kemampuan Pemecahan Masalah. Jurnal Tatsqif. 16(2):164.

Setyowati Nanik. (2009). Jenis-Jenis Gulma yang Berpotensi sebagai Tanaman Obat bagi Masyarakat Desa Taba Teret, Taba Penanjung, Bengkulu. Jurnal Etnobotani.

Wiwin Eka Rahayu, Sudarmin. (2015). Pengembangan Modul Ipa Terpadu Berbasis Etnosains Tema Energi Dalam Kehidupan Untuk Menanamkan Jiwa Konservasi Siswa. Unnes Science Education Journal. 920.

Zufahmi \& Zuraida. (2017). Keanekaragaman Jenis Tanaman Obat Di Kecamatan Peukan Baro Kabupaten Pidie. Jurnal Agroristek. 1(1):4. 